\title{
Investigating the Efficiency of GCC Banking Sector: An Empirical Comparison of Islamic and Conventional Banks
}

\author{
Imran Khokhar ${ }^{1}$, Mehboob ul Hassan ${ }^{2}$, Muhammad Nauman $\operatorname{Khan}^{3} \&$ Md Fouad Bin Amin ${ }^{2}$ \\ ${ }^{1}$ Department of Economics, College of Business Administration, King Saud University, Riyadh, Saudi Arabia \\ 2 Islamic Banking Center, Department of Economics, College of Business Administration, King Saud University, \\ Riyadh, Saudi Arabia \\ ${ }^{3}$ Department of Finance, College of Business Administration, King Saud University, Riyadh, Saudi Arabia \\ Correspondence: Mehboob ul Hassan, Islamic Banking Center, Department of Economics, College of Business \\ Administration, King Saud University.
}

Received: September 2, 2019

doi:10.5430/ijfr.v11n1p220
Accepted: October 27, 2019

Online Published: November 7, 2019

URL: https://doi.org/10.5430/ijfr.v11n1p220

\begin{abstract}
We examine and compare the performance of 63 (21 Islamic and 42 conventional) GCC banks at two tiers, covering the period of 2010-2016. In the first tier, an industry-level analysis is conducted of each country, followed by an individual bank-level analysis in the second tier. Deposits, assets, and capital are taken as inputs to measure the outputs using data envelopment analysis techniques. At the industry level, we find that Islamic banking is at par with-if not better than-conventional banking in all terms of efficiency. Particularly, banking in Bahrain and KSA is among the best, whereas there is no scope for improvement in the UAE's banking industry. This low performance could be attributed to a lack of standardization in products and schemes as well as the level of prudence in decision-making, governance, and operations. At the bank level, many Islamic banks perform even better than conventional banks. Most studies on GCC and MENA focus on the determinants and indicators of development and the banking industry growth in general. Uniquely, we further examine GCC banking performance at the individual bank level by incorporating the latest available data.
\end{abstract}

Keywords: Islamic and conventional banking, efficiency, comparative performance, data envelopment analysis

\section{Introduction}

Since the last quarter of $20^{\text {th }}$ century, global actors have sought a feasible alternative to capitalism. The impetus for this search for a new paradigm has come from the series of financial crises that have occurred at a global scale, first starting from the West, and then spread to other regions, such as the 2007-2008 Global Financial Crisis, which began in the U.S. As a result, the global economy, as well individuals, held billions of dollars in outstanding mortgage. The gross total private sector debt amounted to twice the gross domestic product, up from $70 \%$ in the 1960 . This debt has triggered economic repression, led to doubts, and has damaged stakeholders' confidence in the reliability of the capitalist financial system. The uncertainty was aggravated when U.S. financial institutions began to default because of debt arising from risky projects and derivatives. The result: a loss of global confidence in financial institutions and the capitalism.

On the contrary, there is rising interest in Islamic banking and finance, primarily because of its realistic nature, its resilience to financial shocks, and the increasing demand for non-conventional financing for customers who wish to avoid interest and speculative projects. Throughout the crises of the last decade, Islamic financial institutions successfully saved themselves because it is characterized by a prohibition on investing into speculative and uncertain business models. It is a highly regulated operation guided by Islamic law, namely, Shari'ah. It is pertinent to note that, during the global financial crises, no Islamic bank was reported to have fallen into insolvency, or sought a bailout from the government or authorities. Islamic finance operates in consonance with the philosophy, spirit, and principles of Islam. The Islamic assertion on financial dealing is to the transform money-lending practices into asset-based financing transactions. The religious law strictly prohibits charging and payment of interest on money-lending practices, but rather encourages its believers to enter into profit-and-sharing contracts for business and consumption. Thus, money is lent without any additional reward on the principal amount. Islam mandates its 
believers to fairly bear the costs and returns of investments and permits only those investments that contribute to the betterment of society.

The rationale and feasibility of Islamic finance as financial intermediation are premised on the fundamental requirement that Islamic financial transactions be supported by an underlying asset and productive activity. This obligation demands Islamic banking and financial institutions to invest their funds after thorough investigation and, thus, yield efficient results and competitive profits for their depositors.

There is a close link between "financial" and "productive" flows in Islamic finance. The intrinsic nature of Islamic finance requires an Islamic banking and a financial institution to be partners in a financial contract compared with the lender-borrower dynamic. This requirement reassures an Islamic bank to bear risk and provide confidence through explicit disclosure and transparency of the roles and responsibilities defined in the contract, a fundamental requirement for governing the Islamic finance industry. The explicitness and transparency of Islamic banking not only contributes to the stability of the Islamic financial system, but it also requires diligent and prudent management. The focus of Islamic investment is on interest-free activities as well as allocative and distributive efficiency.

Since the inception of the Islamic Development Bank, Dubai Islamic Bank, and Kuwait Finance House in the 1970s, Islamic assets and wealth management in the Middle East has burgeoned. Diverse and innovative Islamic investment funds have made the Cooperation Council for the Arab States of the Gulf, or GCC, a hub of Islamic banking and finance. The region spearheads and leads supervision in Shari'ah, accounting, and auditing of the Islamic banking industry. Starting with Islamic Developing Bank, the Islamic financial industry of the GCC has been facilitating the flow of capital within Middle East as well as in Africa, Asia, and the West, thus strengthening Islamic financial architecture.

As the banking sector's growth is believed to be tied with economic development, the banking industry of GCC too has a significant share in the economy of GCC region. This makes it valuable to study the performance of the GCC banking sector. It is equally important to examine the ability of bank management to maintain the confidence and trust of stakeholders. From an internal perspective, it would help bank management examine the success of its managerial decisions as well as formulate strategic plans for the future. Above all, a cross-country study, such as ours, will aid banking management and policymakers in comparing the success of their decisions with those made by their neighboring counterparts during the observed period.

In this study, we conduct an analysis at two levels. At the first level, we examine and compare the performance of the GCC banking industry at the sector level. At the second level, we examine the performance at the individual country and bank level. This two-tiered analysis has a dual purpose: First, it provides an overview of the Islamic banking industry and its growth in the GCC, that is, insights on the banking industry of Middle East. Second, it attempts to measure the performance of the GCC Islamic banking industry in comparison with conventional banking within the same region from an efficiency perspective. Further, it will help banking management to learn the strengths and weaknesses of their decisions and policy formulation, while also helping investors select the best bank for their investments.

The study of Islamic banking in GCC is significant for researchers because the region holds $66 \%$ of the global Islamic finance assets (WEF, 2015) and links the flow of finance between Middle East, Asia, Africa, and rest of the world. Moreover, awareness among depositors and investors has increased tremendously, making them keener about the use of their resources.

\subsection{Global Islamic Finance Industry}

During the last three decades, the Islamic banking and financial industry expanded globally, with greater asset accumulation and institutional formation. Many new financial and investment products were developed to meet the growing needs of individuals and corporates. Today, the Islamic banking and financial industry comprises more than 500 banking and financial institutions, with an average annual growth rate of $15-20 \%$. It has become an integral part of the global financial industry. The aggregate sum of wealth under the management of this industry is estimated to be $\$ 2.43 \mathrm{tn}$, which, according to some opinions, is substantially below its potential of $\$ 4.84 \mathrm{tn}$.

Home to the world's largest Islamic banking institutions, such as Al-Rajhi, Kuwait Finance House, Abu-Dhabi Islamic Bank, and Dubai Islamic Bank, the Islamic banking industry of GCC has evolved and expanded in a rapidly changing, dynamic, and competitive global environment. In this context, issues of efficiency, compatibility, and competitiveness have become crucial, especially when an emerging industry has another industry rivalry. 


\subsection{Islamic Banking Industry in the GCC}

Since the inception of the modern Islamic banking and financial industry, the GCC has captured a dominant position globally. The estimated size of the GCC Islamic finance industry assumes that the potential size of the industry grows by at least $17 \%$ annually. The growth is based on many factors such as:

- After the 2007-2008 Global Financial Crisis, which spread from the U.S. to the world, including Europe, Australia, and Japan, GCC has become an emerging hub for Islamic finance.

- The global Muslim population continues to grow and move to GCC member countries for better opportunities.

- Awareness about Islamic banking and finance continues to rise, even among non-Muslims.

- Islamic banking has proven itself to be resilient against financial shocks and crises due to its underlying asset provision and profit-and-loss sharing requirements in financial contracts.

- Along with the increase in the global Muslim population, the per capita income of the Muslim world is also on the rise. To meet the increasing demand in halal, or permissible, goods and services such as food, cosmetics, and fashion, the Islamic financial industry has become an essential, with growth passing new milestones.

In the subsequent section we will provide a country-wise overview of the Islamic banking industry.

Saudi Arabia is a key player in the financial industry of GCC; it has 12 local banks (eight are conventional and four are Islamic) and 14 licensed branches of international banks. The conventional banks are Riyadh Bank, Saudi Investment Bank, Banque Saudi Fransi, Saudi British Bank, Arab National Bank, Samba Financial Group, The National Commercial Bank (NCB), and Alawwal Bank. Its Islamic banks are Al-Bilad, Al-Inma, Al-Jazira Bank, and Al-Rajhi. Among these banks, NCB (with assets of more than SAR 437.5bn) is the largest for its balance sheet size, which represents $20.0 \%$ of the total market. Al-Rajhi Bank (asset base of SAR 349.2bn and 15.9\% market share), Samba (asset base of SAR 228.9bn and 10.4\% market share), and Riyadh Bank (total assets worth SAR 213.7bn and 9.7\% market share) follow next. The four Islamic banks held roughly $27 \%$ of the total banking assets, whereas Al-Rajhi Bank alone maintained 58.5\% of the total market share in 1Q2018 (marginally up from 58.2\% in Q4 2017). (Saudi Banking Sector Quarterly Report, Q1-2018 Al Jazira Capital, May, 2018) Although the share of Islamic banking industry is relatively smaller than that of conventional banks, the former is rising gradually because of local and regional demands. The first Islamic bank, Al-Rajhi started its operation in 1950s and is considered the largest bank in Saudi Arabia for assets.

UAE, like Saudi Arabia, also made a remarkable contribution in the establishment and development banking industry. There are 22 locally incorporated banks in the UAE, 6 GCC banks, and 21 foreign banks whose total assets increased by $1.1 \%$ (AED $2748.9 \mathrm{bn}$ ) at the end of Q2 2018 compared with the quarterly increase of $0.2 \%$ at the end of the Q2 2017. Between June 2017 and June 2018, its total banking assets increased by 4.4\% (United Arab Emirates, Monetary, Banking \& Financial Markets Developments 2018 - 2nd Quarter Report, July). With the establishment of Dubai Islamic Bank in 1975, the country is widely regarded as a pioneer in promoting Islamic banking both in regulations and practices. The UAE holds almost 32\% share in global Islamic banking assets. However, the share of Islamic banks in its domestic market is relatively small, that is, $19 \%$. The UAE is home to 8 Islamic banks and 26 Islamic banking windows equally divided into local and foreign banks. In addition to banking institutions, the country has 12 Islamic finance companies and 1 Islamic investment company.

Bahrain set the benchmark in Islamic banking rules, regulations, and standards by establishing the Bahrain Islamic Bank as early as in 1978. It is recognized as the global leader in Islamic banking and finance. Bahrain has the largest concentration of Islamic finance institutions in the region. Both conventional and Islamic banks have largely captured the financial market, accounting for more than $85 \%$ of the total financial assets. There are 23 retail banks, 69 wholesale banks, 2 specialized banks, and 36 representative offices of overseas banks under conventional banking. In addition to this, there are 6 retail and 18 wholesale Islamic banks that offer innovative Shari'ah-compliant products and services. Some of the retail Islamic Banks in Bahrain are Al Baraka Islamic Bank (Bahrain), Al-Salam Bank (Bahrain), Bahrain Islamic Bank, Ithmaar Bank, Khaleeji Commercial Bank, and Kuwait Finance House (Bahrain), whereas the wholesale Islamic Banks are ABC Islamic Bank, Al Baraka Banking Group, Arab Islamic Bank, Bank Al-Khair, Citi Islamic Investment Bank, First Energy Bank, GFH Investment Bank, Global Banking Corporation, Ibdar Bank, International Investment Bank, Investment Dar Bank, Investors Bank, Kuwait Turkish Participation Bank Inc., and Liquidity Management Center. Foreign banks offer Islamic financial products and services via Islamic banking too. These banks include Capital Management House, First Energy Bank, Standard Chartered Bank, Elaf Bank B.S.C, Capinnova Investment Bank, Kuwait Finance House, and HSBC Amanah. 
Qatar has both conventional and Islamic banking systems. It has eleven local banks, namely, Ahli Bank Qatar, Al Khaleeji Bank, The Commercial Bank of Qatar, DOHA Bank, International Bank of Qatar, Masaf Al Rayan, Qatar Development Bank, Qatar Islamic Bank, Qatar National Bank, QIIB, and Barwa Bank as well a one foreign bank, namely, HSBC Bank Middle East. The country has also proven to be an emerging hub for the global Islamic finance industry. There are four proper Islamic commercial banks; one corporate Islamic bank; and domestic, regional, and international conventional financial institutions.

The Kuwaiti banking sector-including domestic banking and foreign bank branches-accounts for about $88 \%$ of the domestic financial sector (banks, investment companies, and insurance and exchange companies). Its domestic banking comprises five Islamic, five conventional, and one specialized bank. It also has banking operations with other countries and this account for $22.4 \%$ of the consolidated banking system (Kuwaiti banks' subsidiaries and branches abroad). In terms of consolidated estimation, conventional banks have been outperforming Islamic banks by capturing $60 \%$ of the market share in the industry as of 2017 . Islamic banks enjoyed about $39 \%$ share in the consolidated banking system, indicating their emerging positions in Kuwait's dual banking system (Financial Stability Report, 2017, Central Bank of Kuwait). The five Islamic banks in Kuwait are Kuwait Finance House, Boubyan Bank, Kuwait International bank, Ahli United Bank, and Warba Bank.

The banking industry in the Sultanate of Oman is as robust as in other GCC countries. The country's banking system, comprising commercial banks, specialized banks, non-banking financial institutions, and leasing companies, is regulated by the Central Bank of Oman. Although there are two proper Islamic banks-Alizz Islamic Bank and Bank Nizwa-some conventional banks such as Ahli Bank, Bank Dohfar, Bank Muscat, National Bank of Oman, HSBC Bank of Oman, and Sohar Bank also offer Islamic banking services through their Islamic windows. Conventional banks dominate the market, whereas Islamic banks have been in a consistent growth phase. The Islamic banking industry of Oman experienced a year-on-year growth of $25 \%$ in 2017, capturing about $13 \%$ of the total banking sector, with total assets of RO $4.1 \mathrm{bn}$ or $\$ 10.65 \mathrm{bn}$.

Table 1. List of Islamic and conventional banks included in the study

\begin{tabular}{|c|c|c|c|c|}
\hline Country & & Conventional Banks & & Islamic Banks \\
\hline \multirow[t]{8}{*}{ Saudi Arabia } & 1 & Arab National Bank & 1 & Bank Albilad \\
\hline & 2 & Riyadh Bank & 2 & Alinma Bank \\
\hline & 3 & Samba Financial Group & 3 & Al-Rajhi Bank \\
\hline & 4 & Saudi British Bank & 4 & Bank Al Jazira \\
\hline & 5 & Saudi Investment Bank & & \\
\hline & 6 & Banque Saudi Fransi & & \\
\hline & 7 & Saudi Hollandi Bank & & \\
\hline & 8 & National Commercial Bank & & \\
\hline \multirow[t]{11}{*}{ United Arab Emirates } & 1 & Abu Dhabi Commercial Bank & 1 & Ajman Bank \\
\hline & 2 & National Bank of Abu Dhabi & 2 & Abu Dhabi Islamic Bank \\
\hline & 3 & Mashreq Bank & 3 & Dubai Islamic Bank \\
\hline & 4 & Amlak Finance & 4 & Emirates Islamic Bank \\
\hline & 5 & Commercial Bank of Dubai & 5 & Sharjah Islamic Bank \\
\hline & 6 & Union National Bank & & \\
\hline & 7 & First Gulf Bank & & \\
\hline & 8 & Bank of Sharjah & & \\
\hline & 9 & Emirates Investment Bank & & \\
\hline & 10 & Gulf Finance House & & \\
\hline & 11 & Invest Bank & & \\
\hline
\end{tabular}




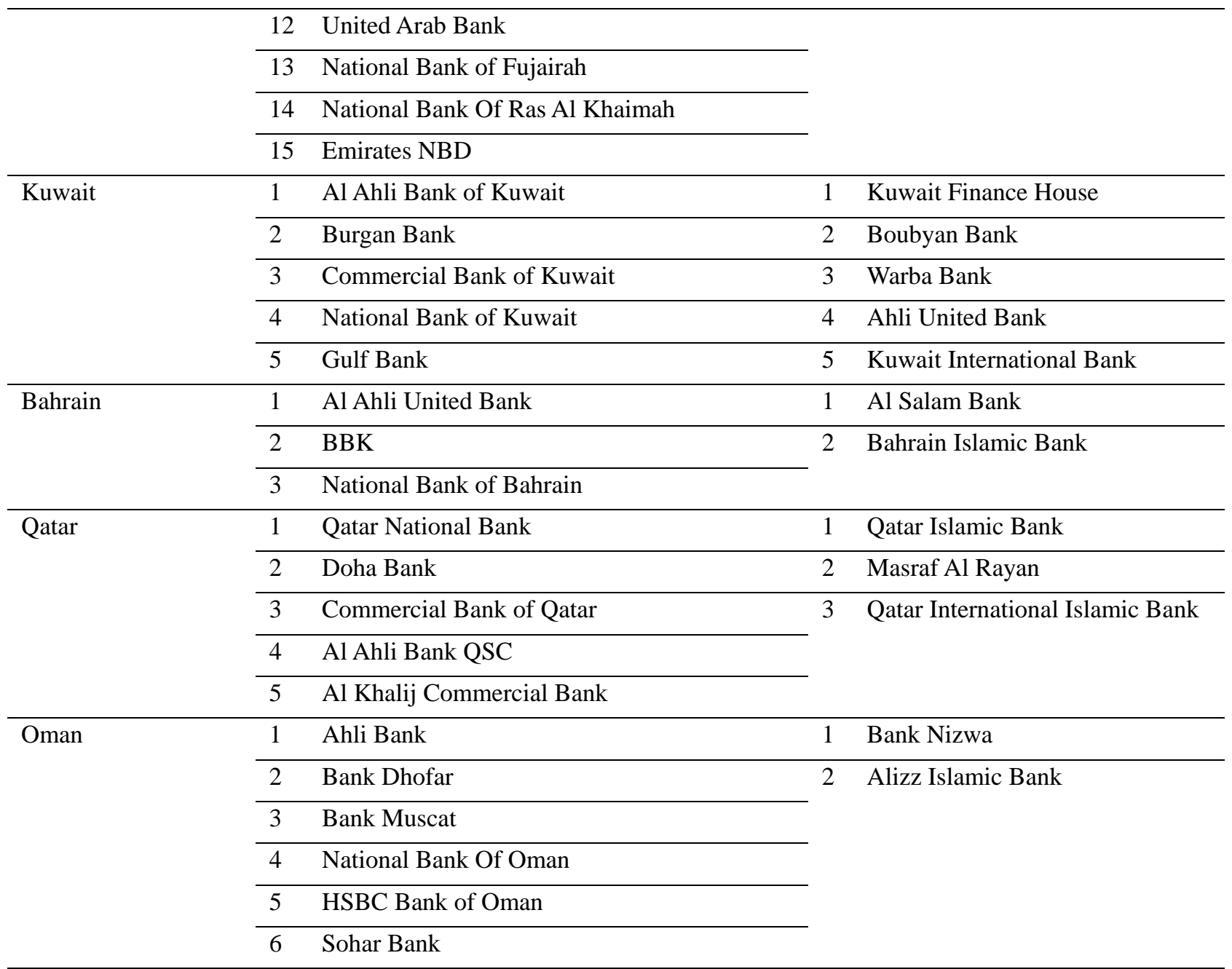

\subsection{Theoretical Background}

There is extensive literature that describes the performance of banks by employing data envelopment analysis (DEA) and stochastic frontier analysis (SFA). Because we compare the performance of Islamic and conventional banks in the GCC, we only reviewed relevant studies.

Sillah, Khokhar, and Khan (2014) analyzed the technical efficiency of 12 Saudi banks with the stochastic frontier, yielding mixed results. In Saudi-foreign ownership, the Banque Saudi Fransi was the most efficient in deposits and investments, whereas Al-Rajhi and Samba were the most efficient in income.

Bukhari and Nizar (2015) used the data of 28 conventional and 20 Islamic banks covering 2006-2012. They used total loans and investments as the output and total deposit, equity, fixed assets, and general expenses as the input variables. They found no significant variance in efficiency of both types of banks in term of constant return to scale, but conventional banks were more efficient in variable returns to scale, particularly in 2009 and 2010. In addition, the efficiency of both types of banks was same in Kuwait, Saudi Arabia, and Qatar, whereas conventional banks were more efficient in Bahrain and the UAE.

Afifa and Ridha (2015) compared conventional and Islamic banks in the MENA region, covering 1990 to 2010. They adopted the SFA and DEA to test for efficiency and stability, discovering that Islamic were slightly better than conventional banks in constant returns to scale. However, conventional banks were better in variable returns to scale. On the contrary, in the SFA approach, Islamic were found to be more stable, cost minimizing, and profitable than conventional banks during 2007-2010.

Ferhi and Chkoundali (2015) used data from 1999 to 2010 to analyze 209 conventional and Islamic banks using the SFA and DEA. In the DEA analysis, Islamic banks were marginally higher than the conventional banks in constant 
returns to scale, whereas conventional banks were higher in variable returns to scale. Some Islamic banks were found to be more efficient in Bahrain, Egypt, Qatar, and Turkey. In the SFA analysis, conventional banks were marginally better than Islamic banks. In some regions such as Saudi Arabia, Qatar, Jordan, Malaysia, Singapore, along with the Russian Federation, the United Kingdom and the Cayman Islands, Islamic banks have the highest cost efficiency,

Bahrini (2017) measured the technical efficiency of Islamic banks in the GCC and MENA region using the bootstrap DEA. The author found that Islamic banks in the GCC were more stable and efficient than in MENA from 2007 to 2008, and even from 2009 to 2010. Miah and Uddin (2017) examined the stability and efficiency of 28 Islamic and 48 conventional banks in the GCC from 2005 to 2014 using the SFA, accounting ratios, and ordinary least square regression technique. They found that conventional banks were better in cost efficiency, whereas Islamic banks were more stable in the short term. However, both types of banks were stable in the long term.

Alshammari (2017) examined conventional and Islamic banks in the GCC for 2003-2015 by considering return on assets and on equity to measure performance. The author found that conventional banks had better profitability that was affected by bank-specific variables such as liquidity, capital adequacy, bank size, and growth. Further, the GCC banks were found to be safe from the 2008 Global Financial Crisis, although their profitability declined at several levels due to regional economic disruption.

Banya and Biekpe (2017) examined ten African countries for 2008-2012 by using the DEA to estimate technical, pure technical, and scale bank efficiency. They also used a truncated bootstrapping approach to find the determinants of efficiency. The results show that bank size is negatively related to banking efficiency, whereas the degree of risk is positively related to it.

Hassan, Khan, Amin, and Khokhar (2018) examined the efficiency of the Saudi Islamic banking industry at the bank level by considering deposits, assets, and capital as inputs and investments, advances, and income as output variables for 2008-2016. They found Al-Rajhi to be the most efficient Islamic bank, followed by Al-Jazira, Al-Inma, and Al-Bilad in that order in technical and pure technical efficiency. However, the technical and scale efficiency scores of Al-Rajhi declined after 2012, whereas Bank Al-Bilad had the highest score in scale efficiency.

Khan, Amin, Khokhar, Hassan, and Ahmed (2018) compared the Saudi conventional and Islamic banking industry to identify the areas requiring strategic measures to improve banking performance. They applied the DEA for data covering 2008 to 2016. According to the results, both conventional and Islamic banks have been successful in improving their levels of efficiency, given the common pledge to expand market share and performance. At the individual bank level, only Al-Rajhi achieved the highest score in technical, pure technical, and scale efficiency. In conventional banking, both Saudi Hollandi and National Commercial banks were found on the top position. Despite the growth of incomes and deposits of the Saudi banking industry, the study recommends Islamic banks to redirect their short- and long-term marketing strategies toward improving management skills at the branch level.

Sharif, Hasan, Kurniasari, Hermawan, and Gunardi (2019) examined the effects of productivity change on efficiency of banks listed on the Malaysian stock exchange, covering 2007 to 2016. In the first stage of the analysis, the authors used the DEA-Malmquist productivity index. The number of fully efficient companies was seven and the results showed that most productivity gains could be attributed to a positive shift in frontier technology and technical efficiency. Based on pure technical efficiency, the performance of Bursa Malaysia's financial companies was relatively stable.

\section{Methodology}

To understand efficiency, one must also understand productive and allocative efficiency. Productive efficiency requires minimum cost to produce, whereas allocative efficiency ensures a firm uses its resources in the best way possible to satisfy consumer preferences. Technical efficiency indicates the ability of a firm to maximize outputs with a given set of inputs. A bank's technical efficiency is its ability to best convert resources into financial services (Bhattacharyya et al., 1997) and it is further divided into pure technical and scale efficiency. Pure technical efficiency tests managerial performance, whereas scale efficiency provides insights to management, so it may choose the optimum quantity of resources to be assigned to the bank size, or so it may choose the scale of production that achieves a predictable production level. This distinction allows us to identify causes of firm inefficiency.

The proportion of the overall technical and pure technical efficiency yields the scale efficiency score, which indicates management's capacity to select the prime level of resources-for instance, the decision on expanding or contracting banking services to achieve the maximum outputs. Thus, scale inefficiency can be of two forms: diminishing returns to scale and increasing returns to scale. If a bank is operating under diminishing returns to scale, it is too large compared with the optimal size, or it is oversized. Conversely, if bank is operating under increasing returns to scale, 
then it is smaller than the optimal size. In most conditions, the scale efficiency scores are built on the variable returns to scale model, ranging between 0 and 1 , which is higher than the constant returns to scale due to the close-fitting of data points. Besides, the acquired score from the variable returns to scale model facilitates decision makers to determine whether the institution is under the procedure of increasing, diminishing, or constant return to scale.

Our study includes 63 banks incorporates, 42 conventional banks, and 21 Islamic banks. We cover a period from 2010 to 2016 based on data availability and reasonable market share. This data range is selected because of the recent advent of some Islamic banks in some GCC countries. DEA is a commonly used method for analyzing the efficiency of any intermediary firm with certain inputs and outputs. The input-oriented efficiency technique of DEA allows us to achieve a given level of output with minimum amount of input. Because we follow a single-year analysis method, the performance of all individual banks is estimated individually and annually. This enables us to obtain the best outcomes in a heterogenic banking industry across the GCC over the observed periods.

Based on the discussion above, assume there are $n$ numbers of firms to be evaluated under following model specification:

$$
\max \mathrm{z}=\sum_{\mathrm{i}=1}^{\mathrm{n}} \mathrm{u}_{\mathrm{i}} \mathrm{y}_{\mathrm{i}}
$$

Subject to

$$
\begin{gathered}
\sum_{i=1}^{n} u_{i} y_{i}-\sum_{j=1}^{m} v_{j} x_{j}-\leq 0 \\
u_{i}, \quad v_{j} \geq 0
\end{gathered}
$$

where $\mathrm{z}$ is the efficiency of the decision-making unit (DMU) under consideration, $u_{i}$ is the $n$ output coefficients of the DMU under consideration, $y_{i}$ is the $n$ output weighting coefficients for the DMU under consideration, $v_{j}=m$ denotes the input coefficients for the DMU under consideration, and $x_{j}=m$ is the input weighting coefficients for the DMU under consideration.

Above equation (1) provides the efficiency score for DMU I, equation (2) transforms the weighted inputs of DMU i equal to 1, and equation (3) confirm that the weighted outputs cannot be more than the weighted inputs for all DMU's (capping efficiency to 1).

Input and Output Specifications: Because the banks transform inputs-that is, deposits, assets, and capital-into output-that is, investment, advances, and net income-the intermediation method under the DEA is the most appropriate for this study. Table 2 presents the variables herein.

Table 2. Description of the variables

\begin{tabular}{lll}
\hline Variables & Notation & Description \\
\hline Inputs & $\mathrm{X} 1$ & Deposits of customers \\
\hline Deposits & $\mathrm{X} 2$ & $\begin{array}{l}\text { Total assets include cash and balance with treasury and other } \\
\text { banks, due from financial institutions, investment, financing, and } \\
\text { other related assets, operating fixed assets, deferred taxed }\end{array}$ \\
\hline Assets & $\mathrm{X} 3$ & $\begin{array}{l}\text { Share capital is the summation of all funds that banks used to raise } \\
\text { by issuing shares. }\end{array}$ \\
\hline Capital & Y1 & Investment \\
\hline Outputs & Y2 & Financing and other related assets \\
\hline Anvestment & Y3 & $\begin{array}{l}\text { Total bank revenues and subtracting the costs of depreciation, } \\
\text { interest, taxes, and other expenses. }\end{array}$ \\
\hline Income & &
\end{tabular}

\section{Results}

Table 3 presents the overall state of the conventional and Islamic banking industries in GCC. The variation among the industries can be attributed to the differences in operational time span, volume, and size of the banks. When we compare the size of the entire banking industry, Saudi banking, with $\$ 76051 \mathrm{mn}$ in assets, leads, followed by Qatar 
(\$54 389mn). We find similar outcomes in investments, where Saudi Arabia leads with \$15 075mn and Qatar follows second with $\$ 933 \mathrm{mn}$. In decomposing the banking industry into Islamic and conventional levels, we find again that Saudi Arabia and Qatar lead accordingly in share size in Islamic banking, with $\$ 28714 \mathrm{mn}$ and $\$ 17315 \mathrm{mn}$, respectively, in their assets buckets. The UAE Islamic banking industry, with $\$ 15882 \mathrm{mn}$ and the Kuwait industry, with $\$ 15782 \mathrm{mn}$, are on the third and fourth positions. Bahrain, though a hub of Islamic banking and finance that first successfully implemented some Islamic banking principles such as equity- and partnership-based financial instruments, have only $\$ 2976 \mathrm{mn}$. Their small size of total assets could be because of its small economy and limited productive sectors. The Omani industry, with $\$ 642 \mathrm{mn}$ as assets, has the least share in GCC Islamic banking industry.

Table 3. Descriptive statistics of variables for 2010-2016 (US\$ millions)

\begin{tabular}{|c|c|c|c|c|c|c|}
\hline \multirow{2}{*}{ Variables } & \multicolumn{3}{|l|}{ Inputs } & \multicolumn{3}{|l|}{ Outputs } \\
\hline & Assets & Deposits & Capital & Loans & Income & Investment \\
\hline \multicolumn{7}{|l|}{ KSA } \\
\hline \multicolumn{7}{|c|}{ Islamic Banks } \\
\hline Mean & 28,714 & 22,566 & 4,619 & 16,394 & 636 & 3,504 \\
\hline S.D & 7,202 & 6,075 & 842 & 3,981 & 98 & 741 \\
\hline \multicolumn{7}{|c|}{ Conventional Banks } \\
\hline Mean & 47,337 & 35,763 & 7,493 & 25,849 & 911 & 11,571 \\
\hline S.D & 7,462 & 5,096 & 1,567 & 4,901 & 160 & 1,620 \\
\hline \multicolumn{7}{|c|}{ Banking Industry } \\
\hline Mean & 76,051 & 58,330 & 12,112 & 42,243 & 1,547 & 15,075 \\
\hline S.D & 11,959 & 8,713 & 1,920 & 6,517 & 191 & 4,358 \\
\hline \multicolumn{7}{|l|}{ UAE } \\
\hline \multicolumn{7}{|c|}{ Islamic Banks } \\
\hline Mean & 15,882 & 11,473 & 2,935 & 8,883 & 204 & 1,737 \\
\hline S.D & 4,097 & 2,939 & 595 & 2,699 & 87 & 540 \\
\hline \multicolumn{7}{|c|}{ Conventional Banks } \\
\hline Mean & 26,886 & 18,089 & 5,227 & 15,427 & 441 & 3,001 \\
\hline S.D & 5,215 & 4,066 & 779 & 2,255 & 137 & 1,351 \\
\hline \multicolumn{7}{|c|}{ Banking Industry } \\
\hline Mean & 42,768 & 29,562 & 8,162 & 24,310 & 644 & 4,738 \\
\hline S.D & 7,273 & 4,838 & 1,363 & 4,152 & 165 & 1,187 \\
\hline \multicolumn{7}{|l|}{ Kuwait } \\
\hline \multicolumn{7}{|c|}{ Islamic Banks } \\
\hline Mean & 15,782 & 8,598 & 3,825 & 7,716 & 138 & 2,743 \\
\hline S.D & 1,487 & 853 & 483 & 761 & 33 & 376 \\
\hline \multicolumn{7}{|c|}{ Conventional Banks } \\
\hline Mean & 24,634 & 9,743 & 3,879 & 13,925 & 279 & 4,291 \\
\hline S.D & 4,594 & 1,320 & 822 & 2,483 & 24 & 546 \\
\hline \multicolumn{7}{|c|}{ Banking Industry } \\
\hline Mean & 40,416 & 18,341 & 7,704 & 21,641 & 417 & 7,035 \\
\hline S.D & 5,644 & 1,222 & 648 & 3,673 & 78 & 921 \\
\hline
\end{tabular}




\begin{tabular}{|c|c|c|c|c|c|c|}
\hline Bahrai & & & & & & \\
\hline Islami & & & & & & \\
\hline Mean & 2,976 & 274 & 1,267 & 877 & 32 & 1,028 \\
\hline S.D & 621 & 65 & 449 & 421 & 7 & 133 \\
\hline Conve & & & & & & \\
\hline Mean & 32,580 & 21,568 & 4,464 & 16,836 & 468 & 6,668 \\
\hline S.D & 3,061 & 3,133 & 572 & 1,342 & 123 & 1,370 \\
\hline Bankir & & & & & & \\
\hline Mean & 35,556 & 21,842 & 5,731 & 17,713 & 500 & 7,696 \\
\hline S.D & 15,506 & 11,252 & 1,731 & 8,336 & 242 & 3,072 \\
\hline Qatar & & & & & & \\
\hline Islami & & & & & & \\
\hline Mean & 17,315 & 2,096 & 3,543 & 9,833 & 365 & 3,197 \\
\hline S.D & 5,552 & 375 & 1,082 & 3,768 & 65 & 1,012 \\
\hline Conve & & & & & & \\
\hline Mean & 37,074 & 23,562 & 7,482 & 22,045 & 713 & 6,135 \\
\hline S.D & 12,559 & 7,575 & 2,139 & 8,048 & 112 & 1,821 \\
\hline Bankir & & & & & & \\
\hline Mean & 54,389 & 25,658 & 11,024 & 31,878 & 1,078 & 9,333 \\
\hline S.D & 13,861 & 12,272 & 2,613 & 8,752 & 201 & 2,080 \\
\hline Oman & & & & & & \\
\hline Islami & & & & & & \\
\hline Mean & 642 & 205 & 307 & 94 & 15 & 181 \\
\hline S.D & 431 & 207 & 151 & 82 & 7 & 126 \\
\hline Conve & & & & & & \\
\hline Mean & 8,511 & 5,618 & 1,661 & 5,533 & 124 & 408 \\
\hline S.D & 2,131 & 1,285 & 482 & 1,325 & 25 & 185 \\
\hline Bankir & & & & & & \\
\hline Mean & 8,969 & 5,764 & 1,880 & 5,600 & 134 & 537 \\
\hline S.D & 4,432 & 2,973 & 823 & 2,976 & 61 & 210 \\
\hline
\end{tabular}

Source: Authors' own calculation, S.D. = Standard Deviation

Table 4 reports a mix trend in all three types of efficiencies among the conventional and Islamic banking industries in the GCC. A comparison of their efficiency shows that Bahrain has the highest level (97\% average score of technical, pure technical, and scale efficiencies), followed by Oman at 95\%, Qatar at 94\%, KSA at 92\%, Kuwait at 91\%, and the UAE at $85 \%$. Bahrain has the highest efficiency level (98\%) for conventional banks, followed by KSA (97\%), Oman (93\%), Qatar (93), Kuwait (93\%), and the UAE (89\%). This overall average efficiency score at the industry level indicates that, in all the six countries, conventional banks have achieved relatively higher scores than their counterparts. This is because GCC Islamic banks in the context of high competition, while implementing Islamic banking principles such as equity- or partnership-based financing. Most importantly, its financial transaction is required to be backed by assets involving many risk factors, particularly in the real-estate market. Clearly, Bahrain is the most efficient in the average efficiency in their both conventional and Islamic banking industry, whereas the least efficient country is the UAE. Although most of the GCC banks are highly concentrated in real-estate investment, this 
sector was adversely affected by the financial crisis of 2007-2008, and the UAE banking sector was severely affected because of its asset bubble.

Islamic banking in Bahrain and Oman are the best performers in terms of pure technical efficiency (0.99 and 0.95), whereas the UAE and Kuwait are the least performing (0.84 and 0.91). This implies that the UAE could avoid wasting $16 \%$ of its inputs on average if its improves its management policies and operational practices. Similarly, for the conventional banking industry, Bahrain and KSA are the best performers ( 0.98 and 0.96$)$, whereas the UAE is the least performing (0.89). Based on the mean values of scale efficiency scores under the Islamic banking industry, Qatar and Bahrain are the best performers (0.97 and 0.96), whereas the UAE again is the least performing (0.93). In conventional banking, KSA, Kuwait, and Bahrain are the best performers ( 0.99 for each), whereas the UAE is the least performing (0.94). Thus, both Islamic and conventional banking in the UAE could save $7 \%$ and $6 \%$ of the resources, respectively, if applied in the best way. This result also speaks to the excellent performance of the Bahraini banking industry in the GCC in both Islamic and conventional banking. This performance is the outcome of three main factors: effective banking regulation, operational expertise, and, mostly importantly, application of Islamic financial instruments. The poor performance of the UAE banking sector could be attributed to its lack of the last two factors, which obstructs maximization of its output in terms of investments, advances or loans, and incomes.

Table 4. Efficiency estimates of Islamic banks

\begin{tabular}{|c|c|c|c|c|c|c|c|c|c|}
\hline Year & 2010 & 2011 & 2012 & 2013 & 2014 & 2015 & 2016 & Mean & SD \\
\hline \multicolumn{10}{|l|}{$K S A$} \\
\hline \multicolumn{10}{|l|}{ Full-fledged Islamic banks } \\
\hline Technical Efficiency & 0.93 & 0.80 & 0.99 & 0.91 & 0.88 & 0.85 & 0.80 & 0.88 & 0.07 \\
\hline Pure Technical Efficiency & 0.98 & 0.95 & 1.00 & 0.97 & 0.92 & 0.88 & 0.84 & 0.93 & 0.06 \\
\hline Scale Efficiency & 0.95 & 0.85 & 0.99 & 0.95 & 0.96 & 0.97 & 0.95 & 0.94 & 0.04 \\
\hline \multicolumn{10}{|l|}{ Conventional Banks } \\
\hline Technical Efficiency & 0.95 & 0.93 & 0.95 & 0.97 & 0.98 & 0.94 & 0.94 & 0.95 & 0.02 \\
\hline Pure Technical Efficiency & 0.96 & 0.96 & 0.96 & 0.98 & 0.98 & 0.95 & 0.95 & 0.96 & 0.01 \\
\hline Scale Efficiency & 0.98 & 0.96 & 0.99 & 0.99 & 0.99 & 0.99 & 0.99 & 0.99 & 0.01 \\
\hline \multicolumn{10}{|l|}{ Banking Industry } \\
\hline Technical Efficiency & 0.94 & 0.89 & 0.96 & 0.95 & 0.94 & 0.91 & 0.91 & 0.93 & 0.03 \\
\hline Pure Technical Efficiency & 0.97 & 0.96 & 0.97 & 0.98 & 0.96 & 0.93 & 0.93 & 0.96 & 0.02 \\
\hline Scale Efficiency & 0.97 & 0.93 & 0.99 & 0.98 & 0.98 & 0.98 & 0.98 & 0.97 & 0.02 \\
\hline \multicolumn{10}{|l|}{$U A E$} \\
\hline \multicolumn{10}{|l|}{ Full-fledged Islamic banks } \\
\hline Technical Efficiency & 0.78 & 0.86 & 0.70 & 0.70 & 0.78 & 0.81 & 0.81 & 0.78 & 0.06 \\
\hline Pure Technical Efficiency & 0.88 & 0.93 & 0.74 & 0.74 & 0.85 & 0.86 & 0.86 & 0.84 & 0.07 \\
\hline Scale Efficiency & 0.89 & 0.92 & 0.94 & 0.94 & 0.93 & 0.94 & 0.94 & 0.93 & 0.02 \\
\hline \multicolumn{10}{|l|}{ Conventional Banks } \\
\hline Technical Efficiency & 0.90 & 0.88 & 0.84 & 0.81 & 0.84 & 0.81 & 0.82 & 0.84 & 0.04 \\
\hline Pure Technical Efficiency & 0.93 & 0.91 & 0.87 & 0.86 & 0.90 & 0.88 & 0.91 & 0.89 & 0.02 \\
\hline Scale Efficiency & 0.97 & 0.97 & 0.96 & 0.94 & 0.94 & 0.93 & 0.90 & 0.94 & 0.02 \\
\hline \multicolumn{10}{|l|}{ Banking Industry } \\
\hline Technical Efficiency & 0.87 & 0.88 & 0.80 & 0.78 & 0.83 & 0.81 & 0.82 & 0.83 & 0.03 \\
\hline Pure Technical Efficiency & 0.92 & 0.91 & 0.84 & 0.83 & 0.88 & 0.87 & 0.90 & 0.88 & 0.03 \\
\hline
\end{tabular}




\begin{tabular}{|c|c|c|c|c|c|c|c|c|c|}
\hline Scale Efficiency & 0.95 & 0.96 & 0.95 & 0.94 & 0.94 & 0.93 & 0.91 & 0.94 & 0.02 \\
\hline \multicolumn{10}{|l|}{ Kuwait } \\
\hline \multicolumn{10}{|l|}{ Full-fledged Islamic banks } \\
\hline Technical Efficiency & 0.93 & 0.81 & 0.83 & 0.84 & 0.85 & 0.89 & 0.94 & 0.87 & 0.05 \\
\hline Pure Technical Efficiency & 0.96 & 0.87 & 0.89 & 0.89 & 0.91 & 0.91 & 0.95 & 0.91 & 0.03 \\
\hline Scale Efficiency & 0.97 & 0.93 & 0.94 & 0.94 & 0.93 & 0.98 & 1.00 & 0.95 & 0.03 \\
\hline \multicolumn{10}{|l|}{ Conventional Banks } \\
\hline Technical Efficiency & 0.96 & 0.91 & 0.90 & 0.88 & 0.89 & 0.89 & 0.87 & 0.90 & 0.03 \\
\hline Pure Technical Efficiency & 0.97 & 0.92 & 0.90 & 0.89 & 0.90 & 0.91 & 0.90 & 0.91 & 0.03 \\
\hline Scale Efficiency & 1.00 & 1.00 & 1.00 & 0.98 & 0.99 & 0.97 & 0.97 & 0.99 & 0.01 \\
\hline \multicolumn{10}{|l|}{ Banking Industry } \\
\hline Technical Efficiency & 0.95 & 0.87 & 0.85 & 0.86 & 0.87 & 0.89 & 0.90 & 0.88 & 0.03 \\
\hline Pure Technical Efficiency & 0.97 & 0.89 & 0.88 & 0.89 & 0.91 & 0.91 & 0.92 & 0.91 & 0.03 \\
\hline Scale Efficiency & 0.98 & 0.97 & 0.97 & 0.96 & 0.96 & 0.97 & 0.98 & 0.97 & 0.01 \\
\hline \multicolumn{10}{|l|}{ Bahrain } \\
\hline \multicolumn{10}{|l|}{ Full-fledged Islamic banks } \\
\hline Technical Efficiency & 0.97 & 0.89 & 0.99 & 0.98 & 0.87 & 1.00 & 0.94 & 0.95 & 0.05 \\
\hline Pure Technical Efficiency & 1.00 & 0.96 & 1.00 & 1.00 & 0.95 & 1.00 & 1.00 & 0.99 & 0.02 \\
\hline Scale Efficiency & 0.97 & 0.92 & 0.99 & 0.98 & 0.91 & 1.00 & 0.94 & 0.96 & 0.04 \\
\hline \multicolumn{10}{|l|}{ Conventional Banks } \\
\hline Technical Efficiency & 0.98 & 0.99 & 0.94 & 1.00 & 0.97 & 0.98 & 0.94 & 0.97 & 0.02 \\
\hline Pure Technical Efficiency & 1.00 & 0.99 & 0.95 & 1.00 & 0.97 & 0.98 & 0.96 & 0.98 & 0.02 \\
\hline Scale Efficiency & 0.98 & 1.00 & 0.99 & 1.00 & 0.99 & 1.00 & 0.98 & 0.99 & 0.01 \\
\hline \multicolumn{10}{|l|}{ Banking Industry } \\
\hline Technical Efficiency & 0.98 & 0.95 & 0.96 & 0.99 & 0.93 & 0.99 & 0.94 & 0.96 & 0.02 \\
\hline Pure Technical Efficiency & 1.00 & 0.98 & 0.97 & 1.00 & 0.96 & 0.99 & 0.98 & 0.98 & 0.01 \\
\hline Scale Efficiency & 0.98 & 0.97 & 0.99 & 0.99 & 0.96 & 1.00 & 0.97 & 0.98 & 0.02 \\
\hline
\end{tabular}

\section{Full-fledged Islamic banks}

\begin{tabular}{llllllllll}
\hline Technical Efficiency & 0.91 & 0.99 & 0.89 & 0.90 & 0.86 & 0.89 & 0.91 & 0.91 & 0.04 \\
\hline Pure Technical Efficiency & 0.94 & 0.99 & 0.89 & 0.91 & 0.87 & 0.94 & 0.96 & 0.93 & 0.04 \\
\hline Scale Efficiency & 0.96 & 0.99 & 1.00 & 0.99 & 0.98 & 0.95 & 0.95 & 0.97 & 0.02 \\
\hline Conventional Banks & & & & & & & & \\
\hline Technical Efficiency & 0.93 & 0.96 & 0.90 & 0.85 & 0.84 & 0.89 & 0.83 & 0.89 & 0.05 \\
\hline Pure Technical Efficiency & 0.96 & 0.98 & 0.95 & 0.85 & 0.86 & 0.89 & 0.84 & 0.91 & 0.06 \\
\hline Scale Efficiency & 0.97 & 0.98 & 0.95 & 0.99 & 0.98 & 1.00 & 0.99 & 0.98 & 0.02 \\
\hline Banking Industry & & & & & & & 0.89 & 0.86 & 0.89 \\
\hline Technical Efficiency & 0.92 & 0.97 & 0.90 & 0.87 & 0.85 & 0.89 & 0.04 \\
\hline Pure Technical Efficiency & 0.95 & 0.99 & 0.93 & 0.87 & 0.87 & 0.91 & 0.89 & 0.91 & 0.04 \\
\hline Scale Efficiency & 0.97 & 0.99 & 0.97 & 0.99 & 0.98 & 0.98 & 0.97 & 0.98 & 0.01 \\
\hline
\end{tabular}




\section{Oman}

\section{Full-fledged Islamic banks}

\begin{tabular}{|c|c|c|c|c|c|c|c|c|c|}
\hline Technical Efficiency & N/A & N/A & 1.00 & 0.95 & 0.87 & 0.95 & 1.00 & 0.95 & 0.05 \\
\hline Pure Technical Efficiency & N/A & N/A & 1.00 & 1.00 & 0.88 & 1.00 & 0.86 & 0.95 & 0.07 \\
\hline Scale Efficiency & N/A & N/A & 1.00 & 0.95 & 0.99 & 0.95 & 0.82 & 0.94 & 0.07 \\
\hline \multicolumn{10}{|l|}{ Conventional Banks } \\
\hline Technical Efficiency & 0.94 & 0.91 & 0.89 & 0.84 & 0.86 & 0.93 & 0.96 & 0.90 & 0.04 \\
\hline Pure Technical Efficiency & 0.99 & 0.97 & 0.93 & 0.88 & 0.91 & 0.99 & 0.99 & 0.95 & 0.05 \\
\hline Scale Efficiency & 0.95 & 0.93 & 0.96 & 0.96 & 0.95 & 0.94 & 0.97 & 0.95 & 0.01 \\
\hline \multicolumn{10}{|l|}{ Banking Industry } \\
\hline Technical Efficiency & 0.94 & 0.91 & 0.91 & 0.87 & 0.86 & 0.93 & 0.91 & 0.90 & 0.03 \\
\hline Pure Technical Efficiency & 0.99 & 0.97 & 0.94 & 0.91 & 0.90 & 0.99 & 0.96 & 0.95 & 0.04 \\
\hline Scale Efficiency & 0.95 & 0.93 & 0.97 & 0.96 & 0.96 & 0.94 & 0.93 & 0.95 & 0.01 \\
\hline
\end{tabular}

Source: Authors' own calculation based on DEA

Table 5 shows that both the Islamic and conventional banking industries in KSA follow a mixed trend. In the UAE, the Islamic banking industry performed relatively well, operating at constant returns to scale from 2012 to 2016 , whereas the conventional industry operates at decreasing returns to scale from 2011 to 2013 and 2015, and increasing returns to scale in 2016. This pattern suggests a careful reconciliation for the UAE conventional banking industry, which may require an increase or decrease in the scale of operations to attain optimality. Islamic banking in Kuwait and Bahrain outperformed the conventional industry in operating at constant returns to scale. In case of Qatar, the industry experienced a consistent performance by operating at constant returns to scale in all the periods, except 2015, whereas the conventional banking industry shows a mixed trend. Lastly, the Omani Islamic banking industry exhibits consistent performance by operating at constant returns to scale during the observed periods, whereas its conventional industry operates at decreasing returns to scale from 2011 to 2013 and increasing returns to scale from 2014 to 2016. Thus, Omani conventional banks are overusing resources, which thus need to be minimized to an optimum level.

Table 5. Estimation of the efficiency frontier

\begin{tabular}{llllllll}
\hline Country & $\mathbf{2 0 1 0}$ & $\mathbf{2 0 1 1}$ & $\mathbf{2 0 1 2}$ & $\mathbf{2 0 1 3}$ & $\mathbf{2 0 1 4}$ & $\mathbf{2 0 1 5}$ & $\mathbf{2 0 1 6}$ \\
\hline KSA & & & & & & & \\
\hline Islamic banks & DRS & CRS & IRS & CRS & CRS & IRS & CRS \\
\hline Conventional Banks & CRS & DRS & IRS & IRS & IRS & DRS & CRS \\
\hline Banking Industry & CRS & DRS & IRS & CRS & DRS & DRS & CRS \\
\hline UAE & & & & & & CRS & CRS \\
\hline Islamic banks & DRS & IRS & CRS & CRS & CRS & CRS & IRS \\
\hline Conventional Banks & CRS & DRS & DRS & DRS & IRS & DRS & IRS \\
\hline Banking Industry & CRS & IRS & DRS & DRS & IRS & DRS & CRS \\
\hline Kuwait & & & & & DRS & DRS \\
\hline Islamic banks & CRS & DRS & CRS & CRS & CRS & IRS & IRS
\end{tabular}




\begin{tabular}{llllllll}
\hline Bahrain & & & & & & & \\
\hline Islamic banks & CRS & DRS & IRS & CRS & DRS & CRS & CRS \\
\hline Conventional Banks & CRS & IRS & DRS & IRS & DRS & IRS & DRS \\
\hline Banking Industry & CRS & DRS & IRS & IRS & DRS & IRS & DRS \\
\hline Qatar & & & & & & & \\
\hline Islamic banks & CRS & CRS & CRS & CRS & CRS & DRS & CRS \\
\hline Conventional Banks & DRS & IRS & DRS & DRS & DRS & IRS & DRS \\
\hline Banking Industry & CRS & IRS & DRS & DRS & DRS & IRS & DRS \\
\hline Oman & & & & & & & \\
\hline Islamic banks & N/A & N/A & CRS & CRS & CRS & CRS & CRS \\
\hline Conventional Banks & CRS & DRS & DRS & DRS & IRS & IRS & IRS \\
\hline
\end{tabular}

Table 6 reports the ranking of GCC banks on technical efficiency. Al-Rajhi Bank of KSA is on the top, followed by Alizz of Oman, Al Ahli United Bank of Bahrain, and Bahrain Islamic Bank. On the other hand, among the ten most least performing banks based on the technical efficiency scores are Bank Nizwa (Islamic) of Oman, HSBC Bank Oman (conventional), and Gulf Finance House (conventional) of the UAE. Four out of top ten best performing or technically efficient banks and not a single technically least efficient bank has been identified under the same category in KSA.

Table 6. Ranking on average, based on technical efficiency (2010-2016)

\begin{tabular}{llllllll}
\hline Top Ten Performing Banks & \multicolumn{7}{l}{ Bottom Ten Performing Banks } \\
\hline Bank & ES & Type & Country & Bank & ES & Type & Country \\
\hline Al-Rajhi Bank & 1.000 & ISL & KSA & Bank Nizwa & 0.747 & ISL & Oman \\
\hline Alizz Islamic Bank & 1.000 & ISL & Oman & HSBC Bank Oman & 0.746 & CON & Oman \\
\hline Al Ahli United Bank & 0.997 & CON & Bahrain & Gulf Finance House & 0.742 & CON & UAE \\
\hline Bahrain Islamic Bank & 0.993 & ISL & Bahrain & Bank Of Sharjah & 0.733 & CON & UAE \\
\hline Masraf Al Rayan & 0.991 & ISL & Qatar & National Bank Of Abu Dhabi & 0.720 & CON & UAE \\
\hline Saudi Hollandi Bank & 0.989 & CON & KSA & Burgan Bank & 0.700 & CON & Kuwait \\
\hline Bank Dhofar & 0.988 & CON & Oman & Sharjah Islamic Bank & 0.691 & ISL & UAE \\
\hline National Commercial Bank & 0.987 & CON & KSA & Amlak Finance & 0.689 & CON & UAE \\
\hline Arab National Bank & 0.978 & CON & KSA & Kuwait International Bank & 0.682 & ISL & Kuwait \\
\hline National Bank Of Kuwait & 0.974 & CON & Kuwait & Emirates Islamic Bank & 0.609 & ISL & UAE
\end{tabular}

Source: Authors' Own Calculation Based On DEA; ES= Efficiency Score, ISL=Islamic, CON=Conventional

Table 7 reports the ranking of GCC banks based on pure technical efficiency. Evidently, Bank Al-Bilad of KSA leads the top ten banks, followed by Al-Rajhi, National Bank of Kuwait, Warda Bank of Kuwait, Al-Ahli United Bank of Bahrain, Bahrain Islamic Bank, and Alizz Islamic Bank of Oman. In contrast, among the ten worst performing bank based on the pure technical efficiency scores are Gulf Finance House of the UAE, Commercial Bank of Qatar of Qatar, HSBC Bank Oman Bank Nizwa of Oman, HSBC Bank Oman, Doha Bank of Qatar, and Kuwait International Bank. Each country from GCC, except the UAE, represents two banks in the top performing list, whereas there is no bank observed from KSA and Bahrain in the list of ten least performing banks. 
Table 7. Ranking based on average pure technical efficiency (2010-2016)

\begin{tabular}{llllllll}
\hline Top Ten Banks & \multicolumn{7}{c}{ Bottom Ten Banks } \\
\hline Bank & ES & Type & Country & Bank & ES & Type & Country \\
\hline Bank Al-Bilad & 1.000 & ISL & KSA & Gulf Finance House & 0.845 & CON & UAE \\
\hline Al-Rajhi Bank & 1.000 & ISL & KSA & Commercial Bank of Qatar & 0.826 & CON & QATAR \\
\hline National Bank of Kuwait & 1.000 & CON & Kuwait & HSBC BANK OMAN & 0.809 & CON & OMAN \\
\hline Warba Bank & 1.000 & ISL & Kuwait & Doha Bank & 0.803 & & QATAR \\
\hline Al Ahli United Bank & 1.000 & CON & Bahrain & Kuwait International Bank & 0.751 & ISL & Kuwait \\
\hline Bahrain Islamic Bank & 1.000 & ISL & Bahrain & Bank of Sharjah & 0.747 & CON & UAE \\
\hline Alizz Islamic Bank & 1.000 & ISL & OMAN & Amlak Finance & 0.716 & CON & UAE \\
\hline Bank Muscat & 0.999 & CON & OMAN & Burgan Bank & 0.714 & CON & Kuwait \\
\hline Qatar National Bank (QNB) & 0.997 & CON & QATAR & Sharjah Islamic Bank & 0.703 & ISL & UAE \\
\hline Masraf Al Rayan & 0.997 & ISL & QATAR & Emirates Islamic Bank & 0.662 & ISL & UAE
\end{tabular}

Source: Authors' own calculation based on DEA, ES= Efficiency Score, ISL=Islamic, CON=Conventional

Table 8 reports the ranking of GCC banks based on scale efficiency. Al-Rajhi Bank leads the top ten banks, followed by Alizz Islamic Bank of Oman, Al Ahli United Bank (conventional) of Bahrain, National Bank of Bahrain (Conventional), and Samba Financial Group (Conventional) of KSA, whereas Emirates Islamic Bank (Islamic) of the UAE is the first on the bottom ten list, followed by Abu Dhabi Islamic Bank of the UAE, Kuwait International Bank (Islamic), Gulf Finance House (conventional) of the UAE, and Dubai Islamic Bank of the UAE. KSA is the only country on the list that has four banks (one Islamic and three conventional), whereas Oman and Bahrain have two banks each in the top ten list. No bank from Kuwait is included in the top ten performing banks. On the contrary, the UAE is the only country in the GCC where three Islamic and three conventional banks are listed in the ten worst performing banks. No bank form Bahrain or Qatar is least performing, indicating their prudent banking management.

Table 8. Ranking based on average scale efficiency

\begin{tabular}{|c|c|c|c|c|c|c|c|}
\hline Top Ten Performing Banks & & & & Least Ten Performing & anks & & \\
\hline Bank & ES & Type & Country & Bank & $\mathbf{E S}$ & Type & Country \\
\hline Al-Rajhi Bank & 1.000 & ISL & KSA & Emirates Islamic Bank & 0.922 & ISL & UAE \\
\hline Alizz Islamic Bank & 1.000 & ISL & OMAN & $\begin{array}{lll}\text { Abu } & \text { Dhabi } & \text { Islamic } \\
\text { Bank } & & \end{array}$ & 0.906 & ISL & UAE \\
\hline Al Ahli United Bank & 0.997 & $\mathrm{CON}$ & Bahrain & $\begin{array}{ll}\text { Kuwait } & \text { International } \\
\text { Bank } & \end{array}$ & 0.905 & ISL & Kuwait \\
\hline National Bank of Bahrain & 0.997 & CON & Bahrain & Gulf Finance House & 0.876 & CON & UAE \\
\hline SAMBA Financial Group & 0.997 & CON & KSA & Dubai Islamic Bank & 0.873 & ISL & UAE \\
\hline Saudi British Bank & 0.997 & CON & KSA & Bank Muscat & 0.857 & CON & OMAN \\
\hline Bank Dhofar & 0.997 & CON & OMAN & Bank Nizwa & 0.850 & ISL & OMAN \\
\hline $\begin{array}{l}\text { National Bank Of Ras } \mathrm{Al} \\
\text { Khaimah }\end{array}$ & 0.996 & $\mathrm{CON}$ & UAE & Bank Al-Bilad & 0.843 & ISL & KSA \\
\hline Doha Bank & 0.996 & $\mathrm{CON}$ & QATAR & Emirates NBD & 0.811 & CON & UAE \\
\hline Saudi Hollandi Bank & 0.996 & CON & KSA & $\begin{array}{l}\text { National Bank of Abu } \\
\text { Dhabi }\end{array}$ & 0.803 & CON & UAE \\
\hline
\end{tabular}

Source: Authors' own calculation based on DEA; ISL=Islamic, $\mathrm{CON}=$ Conventional 


\section{Conclusion}

We examined and compared the performance of Islamic and conventional banking at an individual and industry level in the GCC. A comparative analysis showed that the Saudi banking industry leading in industry size, followed by Qatar. We found the same results for investments, where Saudi Arabia leads and Qatar has the second largest share in the banking industry. After decomposing the banking industry into Islamic and conventional banking, Saudi Arabia and Qatar still take the first and second positions, respectively, followed by the UAE and Kuwait. Bahrain, despite being its important position in the industry, has a relatively small share and Oman has the least.

The statistical analysis of comparative performance regarding efficiency showed a mix trend among the conventional and Islamic banking industries. Overall, the average efficacy score at the industry level indicates that conventional banks have higher scores than their counterparts. Moreover, Bahrain is most efficient in the average efficiency of conventional and Islamic banking, whereas UAE is the least efficient.

Examining the efficiency at country level indicated that the Bahraini Islamic banking industry is best performing, followed by KSA. Despite Oman's small share, its Islamic banking industry performs well and stand equal to Qatar and Kuwait's industries. On the other hand, though the UAE has the second largest share in the region, its performance is less than the average. For the conventional banking industry, we found that Bahrain leads, whereas the UAE banking industry needs improvements. At the individual bank level, two banks from each GCC country, except Bahrain and KSA, are in the list of least performing banks. Thus, the latter two exhibit efficient and prudent bank management.

The outcomes at the industry level show that Kuwait, Bahrain, and KSA are among the best, whereas banking in the UAE is the least performing. At the individual bank level, Al-Rajhi Bank of KSA leads, followed by Alizz Islamic Bank. An examination of the returns to scale also revealed a mix trend for both industry types. However, the period of increasing returns to scale is far longer in Islamic banking than in conventional banking, indicating better management performance. Overall, KSA leads in the GCC at both the industry and individual bank levels.

Thus, we conclude that the variations in the outcomes of banking performance are due to difference in banking history, experience, size, prudence in decision-making, governance, and operational processes at the bank level. The results are important for policy implications in the respective banks should they seriously seek to achieve desired outcomes. Our results might also help management to reconsider their decisions with deliberate care and effectiveness. A further study to compare the performance of the GCC banking industry with other regions would benefit the larger readership as well as stakeholders of the Islamic and conventional banking industry

\section{Acknowledgements}

The authors thank the Deanship of Scientific Research, represented by the research center at College of Business Administration, KSU for financial and technical support.

\section{References}

Ajlouni, M. M., Hmedat, M. W., \& Hmedat, W. (2011). The relative efficiency of Jordanian banks and its determinants using data envelopment analysis. Journal of Applied Finance \& Banking, 1(3), 33-58.

Akhtar, M. A., \& Sadaqat, S. (2011). Factors influencing the profitability of Islamic banks of Pakistan. International Research Journal of Finance and Economics, 66, 125-132.

Al-Faraj, T. N., Bu-Bshait, K. A., \& Al-Muhammad, W. A. (2006). Evaluating the efficiency of Saudi commercial banks using data envelopment analysis. International Journal of Financial Services Management, 1(4), 466-477. https://doi.org/10.1504/IJFSM.2006.010124

Almazari, A. A., \& Almumani, M. A. (2012). Measuring profitability efficiency of the Saudi national banks. International Journal of Business and Social Science, 3(14), 176-185.

Almumani, M. A. (2013). The relative efficiency of Saudi banks: data envelopment analysis models. International Journal of Academic Research in Accounting, Finance and Management Sciences, 3(3), 152-161. https://doi.org/10.6007/IJARAFMS/v3-i3/115

Aly, H., Grabowski, R., Pasurka, C., \& Rangan, N. (1990). Technical, scale, allocative efficiency in US banking: an empirical investigation. The Review of Economics and Statistics, 72(2), 211-218. https://doi.org/10.2307/2109710

Bahrini, R. (2017). Efficiency analysis of Islamic banks in the Middle East and North Africa region: a bootstrap DEA approach. International Journal of Financial Studies, 5(1), 1-13. https://doi.org/10.3390/ijfs5010007 
Bukhari, M. S. S., \& Harrathi, N. (2015). Bank efficiency analysis: Islamic banks versus conventional banks in the Gulf Cooperation Council Countries 2006-2012. International Journal of Financial Research, 6(4), 143-150. https://doi.org/10.5430/ijfr.v6n4p143

Charnes, A., Cooper, W. W., \& Rhodes, E. (1978). Measuring the efficiency of decision making units. European Journal of Operational Research, 2(6), 429-444. https://doi.org/10.1016/0377-2217(78)90138-8

Cooper, W., Seiford, L. M., \& Zhu, J. (2000). Data Envelopment Analysis. Boston, MA: Kluwer Academic Publishers.

Favero, C. A., \& Papi, L. (1995). Technical efficiency and scale efficiency in the Italian banking sector: a nonparametric approach. Applied Economics, 27(4), 385-395. https://doi.org/10.1080/00036849500000123

Ferhi, A., \& Chkoudali, R. (2015). Islamic and conventional banks: Efficiency and stability during the current crises. Journal of Research in Economics and International Finance, 4(2), 27-33.

Hassan, M., Khan, M. N., Amin, M. F., \& Khokhar, I. (2018). Measuring the performance of Islamic banks in Saudi Arabia. International Journal of Economics and Management, 12(1), 99-115.

Isik, I., \& Hassan, M. (2002). Technical, scale and allocative efficiencies of Turkish banking industry. Journal of Banking and Finance, 26(4), 719-766. https://doi.org/10.1016/S0378-4266(01)00167-4

Jarrah, I. M. (2007). The use of DEA in measuring efficiency in Arabian banking. Banks and Bank Systems, 2(4), 21-30.

Johnes, J., Izzeldin, M., \& Pappas, V. (2013). A comparison of performance of Islamic and conventional banks 2004-2009. Journal of Economic Behavior \& Organization, 103[Supplement], 93-107. https://doi.org/10.1016/j.jebo.2013.07.016

Kamaruddin, B. H., Safa, M. S., \& Mohd, R. (2008). Assessing production efficiency of Islamic banks and conventional bank Islamic windows in Malaysia. International Journal of Business and Management Research, $1(1), 31-48$.

Khan, M. N., Amin, M. F., Khokhar, I., Hassan, M., \& Ahmed, K. (n.d.). Efficiency measurement of Islamic and conventional banks of Saudi Arabia: an empirical and comparative analysis. Accepted for publication in IIiBF's Special Issue on Islamic Banking and Finance for 2018 in Al-Shajarah.

Kwan, S. (2002). The X-efficiency of commercial banks in Hong Kong. Working Paper Series No. 2002-14 (pp.1-30). Federal Reserve Bank of San Francisco. https://doi.org/10.24148/wp2002-01

Mester, L. (1997). Measuring efficiency at US banks: accounting for heterogeneity is important. European Journal of Operational Research, 98(2), 230-242. https://doi.org/10.1016/S0377-2217(96)00344-X

Miah, M. D., \& Uddin, H. (2017). Efficiency and stability: a comparative study between Islamic and conventional banks in GCC countries. Future Business Journal, 3(2), 172-185. https://doi.org/10.1016/j.fbj.2017.11.001

Noor, M. A., \& Ahmad, N. H. (2012). The determinants of efficiency of Islamic banks. The IUP Journal of Bank Management, 11(2), 32-70.

Saeed, S., Ali, F., Adeeb, B., \& Hamid, M. (2013). Examining efficiency of Islamic and conventional banks in Pakistan: using data envelopment analysis. Global Journal of Management and Business Research Finance, 13(10), 1-11.

Sealey, C., \& Lindley, J. (1977). Inputs, outputs, and a theory of production and cost at depository financial institutions. The Journal of Finance, 32(4), 1251-1266. https://doi.org/10.1111/j.1540-6261.1977.tb03324.x

Sharif, O., Hasan, M., Kurniasari, F., Hermawan, A., \& Gunardi, A. (2019). Productivity and efficiency analysis using DEA: Evidence from financial companies listed in Bursa Malaysia. Management Science Letters, 9(2), 301-312. https://doi.org/10.5267/j.msl.2018.11.010

Sillah, B. M., Khokhar, I., \& Khan, M. N. (2014). The performance of Saudi Banking industry 2000-2011: have the banks distinguished themselves from one another?. International Journal of Financial Research, 5(2), 1-12. https://doi.org/10.5430/ijfr.v5n2p121

Zainal, S., \& Ismail, M. (2012). Shari'ah compliant banking efficiency: A DEA approach. 3rd International Conference on Business and Economic Research (3rd ICBER), Malaysia. 